Jurnal PAI Raden Falah

Vol. 2, No. 2, (April 2020): 183-201

\title{
KORELASI ANTARA PENGALAMAN MENGAJAR DENGAN KOMPETENSI PROFESIONAL GURU PAI DI MADRASAH ALIYAH NEGERI 3 PALEMBANG
}

Destri Rahayu

Universitas Islam Negeri Raden Fatah Palembang

destri_rahayu18@gmail.com

Akmal Hawi

Universitas Islam Negeri Raden Fatah Palembang

akmalhawi@radenfatah.ac.id

Mardeli

Universitas Islam Negeri Raden Fatah

Palembang

mardeli@radenfatah.ac.id

Sofyan

Universitas Islam Negeri Raden Fatah

Palembang

sofyan_uin@radenfatah.ac.id

\section{Abstract}

The teacher is one of the dominant factors that is important in formal education. To improve the quality of education, one of the requirements is to improve the quality of educators, namely teachers. Teachers are part of a system that largely determines education. There are many things that improve a teacher's performance. One of them is teaching experience. With this teacher can have various kinds of skills, expertise and abilities needed in teaching and learning activities. Likewise, it will also be discussed with further education about teacher competencies. The time used by the teacher when teaching is still lacking in discipline, it can be seen that the compilation of class hours has begun, the teacher is still late in class. The purpose of this study was to study the relationship of teacher teaching experience with professional competence in Madrasah Aliyah Negeri 3 Palembang.

This type of research is a type of quantitative research. Data collection techniques are done by questionnaire, and documentation. The questionnaire was used by researchers to see how the teaching experience and competence of professional teachers is. The data analysis technique in this study used a $t$ questionnaire to seek knowledge about teaching experiences with PAI professional teacher competencies in Madrasah Aliyah Negeri 3 Palembang or not.

The results of this study are that there is a significant relationship between teaching experience with professional competence using the formula "product moment conversations" in Microsoft Excel, namely t-table $10.4157 \geq 0.8597$. Then the alternatives received in other words contained between the significance of teaching experience with PAI's professional competence at Madrasah Aliyah Negeri 3 Palembang.

Keywords: Teaching Experience, Professional Competence 


\section{PENDAHULUAN}

Pengalaman guru dalam mengajar dan melaksanakan tugas sebagai pendidik merupakan suatu hal yang berharga. Tingkat kompetensi profesional di duga dipengaruhi oleh pengalaman mengajar guru. Menurut Wibowo mengemukakan bahwa pengalaman merupakan elemen yang perlu, tetapi untuk menjadi ahli tidak cukup dengan pengalaman. ${ }^{1}$ Namun demikian, pengalaman merupakan aspek lain kompetensi yang dapat berubah dengan perjalanan waktu dan perubahan lingkungan. Menurut Uno pada dasarnya perubahan perilaku yang ditunjukkan peserta didik dipengaruhi oleh latarbelakang pendidikan dan pengalaman. Semakin berpengalaman guru dalam mengajar semakin luas materi pelajaran yang dikuasai sehingga memungkinkan dalam meningkatkan kompetensi profesionalnya. $^{2}$

Sekolah adalah lembaga pendidikan yang diselenggarakan dalam waktu yang sangat teratur, program yang sangat kaya dan sistematik, dilakukan oleh tenaga kependidikan yang profesional dalam bidangnya dan dilengkapi dengan fasilitas yang memadai. Sekolah pada dasarnya merupakan lembaga tempat proses pembelajaran terjadi, belajar dilakukan oleh siswa dan guru berupaya untuk melaksanakan proses belajar mengajar siswa dengan baik agar dapat mencapai kompetensi yang diharapkan. Sekolah sebagai lembaga pendidikan formal, terdiri dari guru (pendidik) dan murid-murid (anak didik). ${ }^{3}$

Menurut Akmal Hawi dalam buku Kompetensi Guru PAI oleh Herman Zaini dan Muhtarom Kompetensi berasal dari bahasa inggris “competence” yang berarti kecakapan dan kemampuan. Menurut Kamus Besar Bahasa Indonesia, kompetensi adalah kewenangan (kekuasaan) untuk menentukan (memutuskan) sesuatu. Kalau kompetensi berarti kemampuan atau kecakapan, maka hal ini erat kaitannya dengan pemilikan pengetahuan, kecakapan atau keterampilan guru. Kata kompetensi secara harfiah dapat diartikan sebagai kecakapan atau kemampuan. Dalam Bahasa Arab, kompetensi disebut dengan kafaah, dan juga alahliyah, yang berarti memiliki kemampuan dan keterampilan dalam bidangnya

\footnotetext{
${ }^{1}$ Wibowo, Manajemen Kinerja (Jakarta: Raja Grafindo Perkasa, 2104), hlm. 284.

${ }^{2}$ Hamzah B. Uno, Profesi Kependidikan (Jakarta: Bumi Aksara, 2012), hlm. 17.

${ }^{3}$ Martina, Nyayu Khodijah, dan Syarnubi "Pengaruh Lingkungan Sekolah Terhadap Hasil Belajar Siswa Pada Mata Pelajaran Pendidikan Agama Islam Di SMP Negeri 9 Tulung Selapan Kabupaten OKI," Jurnal PAI Raden Fatah 1 (2), hlm 80.
} 
sehingga ia mempunyai kewenangan atau otoritas untuk melakukan sesuatu dalam batas ilmunya tersebut. ${ }^{4}$

Kompetensi guru adalah seperangkat penguasaan kemampuan yang harus ada pada diri guru agar dapat mewujudkan kinerjanya secara tepat dan efektif. Untuk dapat menjadi guru yang memiliki kompetensi, maka harus memiliki kemampuan untuk mengembangkan empat aspek tercantum dalam UndangUndang Guru dan Dosen No. 14 Tahun 2005 pasal 10 ayat 1, yaitu meliputi kompetensi pedagogik, kompetensi kepribadian, kompetensi profesional dan kompetensi sosial yang diperoleh melalui pendidikan profesi. ${ }^{5}$

\section{METODE PENELITIAN}

Dalam penelitian ini, penulis menggunakan jenis penelitian deskriptif kuantitatif. Pendekatan kuantitatif adalah metode penelitian yang berdasarkan pada filsafat positivisme, digunakan untuk meneliti pada populasi atau sampel tertentu, teknik pengumpulan data menggunakan instrumen penelitian, analisis data bersifat kuantitatif/statistik dengan tujuan untuk menguji hipotesis yang telah ditetapkan. $^{6}$

Adapun teknik analisis yang digunakan untuk menganalisis data dalam penelitian ini adalah sebagai berikut: setelah data-data dikumpulkan, selanjutnya data dianalisis secara deskriptif kuantitatif yaitu dengan cara membahas, menjabarkan, menguraikan dan mencari hubungan-hubungan masalah yang telah ditelaah kemudian ditarik kesimpulan secara deduktif yang menarik kesimpulan dari penjelasan-penjelasan yang bersifat umum ditarik ke khusus sehingga penyajian hasil penelitian dapat dimengerti. Analisis data pada penelitian ini menggunakan Product Moment.

Data kuantitatif adalah data yang berbentuk angka, atau data kualitatif yang diangkakan. ${ }^{7}$ Data kuantitatif dapat di ukur karena mengandung besaran yang

${ }^{4}$ Herman Zaini, Kompetensi Guru PAI (Palembang: NoerFikri Offset, 2015), hlm. 1.

${ }^{5}$ Rojai, Panduan Sertifikasi Guru Berdsarkan Undang-Undang Guru dan Dosen (Jakarta: Dunia Cerdas, 2013), hlm. 11.

${ }^{6}$ Supardi, Metodologi Penelitian Pendidikan (Jakarta: Bumi Aksara, 2007), hlm. 14.

${ }^{7}$ Sugiyono, Metode Penelitian Kuantitatif, Kualitatif, dan Kombinasi (Mix Methods) (Bandung: Alfabeta, 2015), hlm. 6. 
dinyatakan dalam angka. ${ }^{8}$ Kuantitatif adalah data hasil observasi atau pengukuran yang dinyatakan dalam angka-angka. Peneliti menggunakan data kuantitatif berupa data angka atau jumlah yakni skor hasil angket.

Data penelitian ini bersumber dari data primer dan data sekunder, data primer yaitu data yang diperoleh dari hasil angket yang disebarkan kepada guru di Madrasah Aliyah Negeri 3 Palembang, penelitian ini diambil secara langsung oleh peneliti dari sumber (responden) yang berupa hasil dari analisis data observasi serta dokumen resmi Madrasah Aliyah Negeri 3 Palembang, data sekunder merupakan data yang dijadikan penunjang dalam penelitian ini, data tersebut berupa dokumen tertulis seperti buku, jurnal, dan dokumentasi berupa foto kegiatan penelitian. Adapun teknik pengumpulan data menggunakan observasi, dokumentasi dan skala.

\section{HASIL DAN PEMBAHASAN}

Penelitian ini dilaksanakan di Madrasah Aliyah Negeri 3 Palembang mulai tanggal 11 Juni sampai dengan 13 Juni 2019. Pelaksanaan penelitian ini dilakukan dengan tiga tahap yaitu tahap perencanaan, tahap pelaksanaan dan tahap pelaporan.

Tahap perencanaan yang dilakukan pada tanggal 11 Juni 2019, pada tahap ini peneliti melakukan observasi ke sekolah untuk mengetahui jumlah guru di Madrasah Aliyah Negeri 3 Palembang. Dari hasil observasi diperoleh, populasi pada penelitian ini yaitu 74 guru, dan yang menjadi sampel penelitian ini terdiri dari 12 guru yang mengajar di bidang keagamaan.

\section{A. Hasil Analisis Deskriptif}

1. Pengalaman Mengajar Guru PAI di Madrasah Aliyah Negeri 3 Palembang. Data pengalaman mengajar guru didapat dari 12 guru PAI dengan menggunakan angket. Angket yang diberikan peneliti kepada responden adalah angket yang berisikan pernyataan mengenai pengalaman mengajar guru. Guru PAI diminta untuk memberikan jawaban pada salah satu

${ }^{8}$ Juliansyah Noor, Metodologi Penelitian: Skripsi, Tesis, Disertai, dan Karya Ilmiah (Jakarta: Kencana, 2011), hlm. 115. 
Vol. 2, No. 2, (April 2020): 183-201

alternatif jawaban yang telah disampaikan yang kemudian dikuantitatifkan menjadi 5, 4, 3, 2, 1 seperti yang telah dijelaskan.

Tabel 1. Jawaban Responden Pada Dimensi Pengalaman Mengajar guru

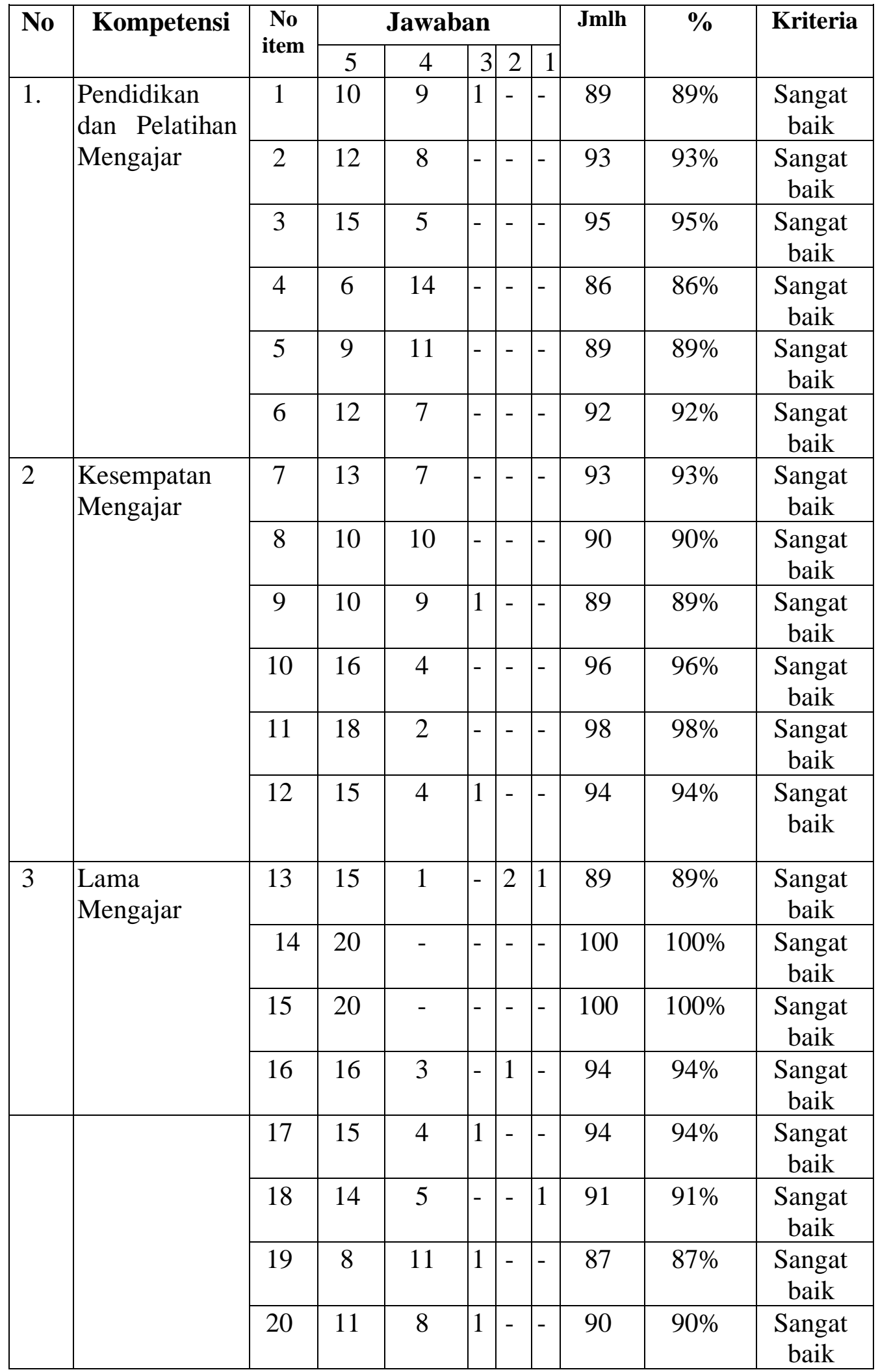




\begin{tabular}{|c|c|c|c|c|c|c|c|c|}
\hline Jumlah & 265 & 122 & 6 & 3 & 2 & 1849 & $92,45 \%$ & $\begin{array}{c}\text { Sangat } \\
\text { baik }\end{array}$ \\
\hline
\end{tabular}

Sumber: (Pengelolahan data primer, 2019)

Berdasarkan data di atas dapat diketahui bahwa secara keseluruhan pengalaman mengajar guru berada dalam kriteria sangat baik dengan persentase $92,45 \%$. Skor tertinggi sebesar $100 \%$ didapatkan pada kompetensi 3 yaitu pengembangan kurikulum, sedangkan skor terendah sebesar $86 \%$ terletak pada kompetensi 1 yaitu Menguasai teori belajar dan prinsip-prinsip belajar yang mendidik.

2. Kompetensi Profesional Guru PAI di Madrasah Aliyah Negeri 3 Palembang.

Data kompetensi profesional guru didapat dari 12 guru PAI dengan menggunakan angket. Angket yang diberikan peneliti kepada responden adalah angket yang berisikan pernyataan mengenai kompetensi profesional guru. Guru PAI diminta untuk memberikan jawaban pada salah satu alternatif jawaban yang telah disampaikan, yang kemudian dikuantitatifkan menjadi 5, 4, 3, 2, 1 seperti yang telah dijelaskan.

\section{Tabel 2. Jawaban Responden Pada Dimensi Kompetensi}

Profesional

\begin{tabular}{|c|c|c|c|c|c|c|c|c|c|c|}
\hline \multirow[t]{2}{*}{ No } & \multirow[t]{2}{*}{ Indikator } & \multirow{2}{*}{$\begin{array}{l}\text { No } \\
\text { item }\end{array}$} & \multicolumn{5}{|c|}{ Jawaban } & \multirow[t]{2}{*}{ Jmlh } & \multirow[t]{2}{*}{$\%$} & \multirow[t]{2}{*}{ Kriteria } \\
\hline & & & 5 & 4 & 3 & 2 & 1 & & & \\
\hline \multirow[t]{5}{*}{1.} & \multirow{5}{*}{$\begin{array}{c}\text { Menguasai mata } \\
\text { pelajaran yang } \\
\text { diampu }\end{array}$} & 1 & 19 & 1 & - & - & - & 99 & $99 \%$ & $\begin{array}{c}\text { Sangat } \\
\text { baik }\end{array}$ \\
\hline & & 2 & 20 & - & - & - & - & 100 & $100 \%$ & $\begin{array}{c}\text { Sangat } \\
\text { baik }\end{array}$ \\
\hline & & 3 & 3 & 11 & 4 & 2 & - & 75 & $75 \%$ & Baik \\
\hline & & 4 & 14 & 5 & 1 & - & - & 93 & $93 \%$ & $\begin{array}{l}\text { Sangat } \\
\text { baik }\end{array}$ \\
\hline & & 5 & 4 & 9 & 7 & - & - & 77 & $78 \%$ & Baik \\
\hline \multirow[t]{7}{*}{2} & \multirow{7}{*}{$\begin{array}{l}\text { Menguasai standar } \\
\text { kompetensi dan } \\
\text { kompetensi dasar } \\
\text { mata pelajaran } \\
\text { yang diampu }\end{array}$} & 6 & 8 & 8 & 4 & - & - & 84 & $84 \%$ & Baik \\
\hline & & 7 & 15 & 4 & 1 & - & - & 94 & $94 \%$ & $\begin{array}{l}\text { Sangat } \\
\text { baik }\end{array}$ \\
\hline & & 8 & 16 & 4 & - & - & - & 96 & $96 \%$ & $\begin{array}{l}\text { Sangat } \\
\text { baik }\end{array}$ \\
\hline & & 9 & 17 & 3 & - & - & - & 97 & $97 \%$ & $\begin{array}{l}\text { Sangat } \\
\text { baik }\end{array}$ \\
\hline & & 10 & 10 & 9 & 1 & - & - & 90 & $90 \%$ & $\begin{array}{l}\text { Sangat } \\
\text { baik }\end{array}$ \\
\hline & & 11 & 11 & 8 & 1 & - & - & 90 & $90 \%$ & $\begin{array}{l}\text { Sangat } \\
\text { baik }\end{array}$ \\
\hline & & 12 & 1 & 5 & 7 & - & 7 & 53 & $53 \%$ & Kurang \\
\hline
\end{tabular}




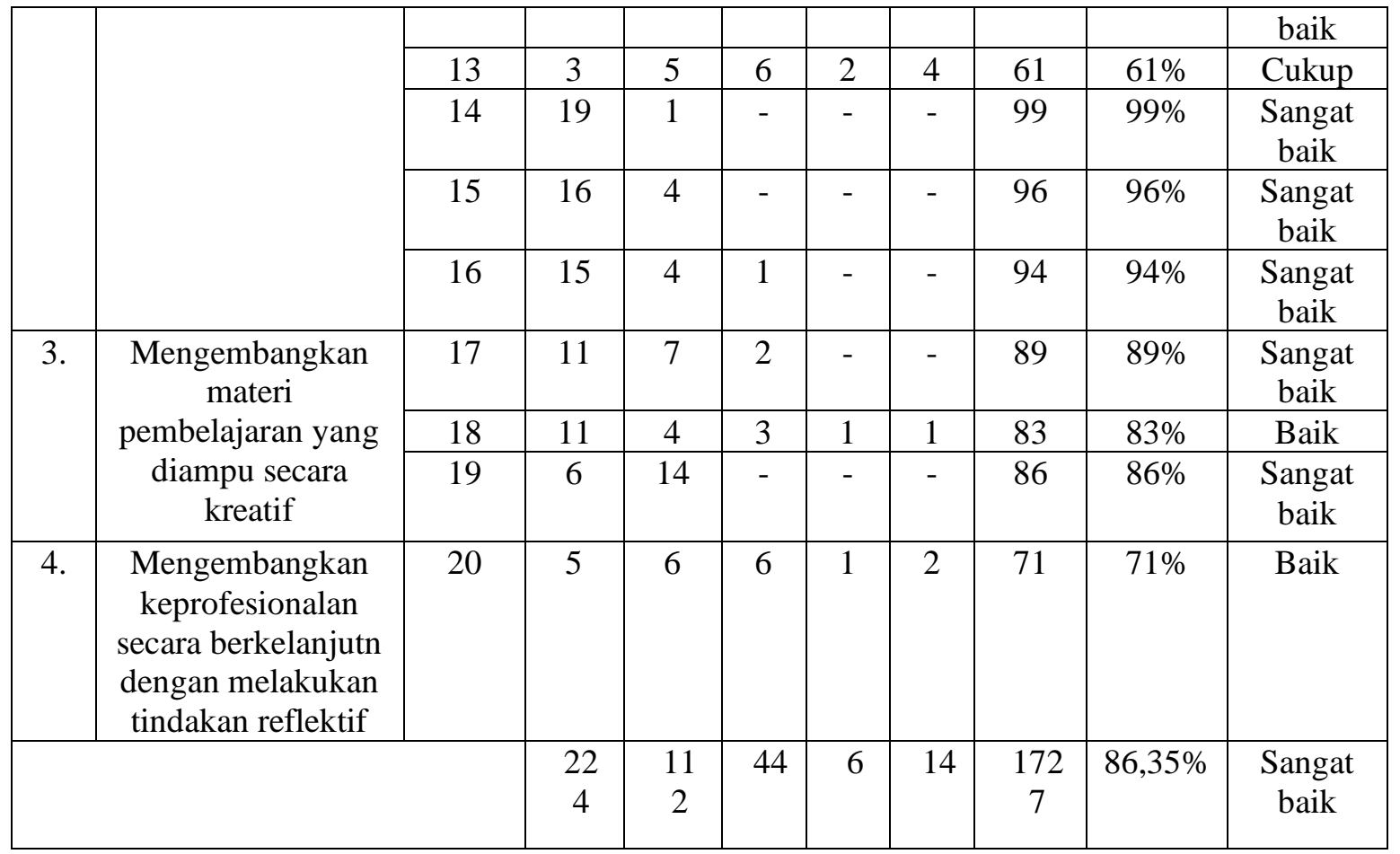

Sumber: (Pengelolahan data primer, 2019)

Berdasarkan data di atas dapat diketahui bahwa secara keseluruhan kompetensi profesional guru berada dalam kriteria sangat baik dengan persentase $86,35 \%$. Dilihat dari jawaban responden pada setiap item pernyataan kuesioner, sebanyak 1 item kurang baik sebesar 53\%, 1 item cukup sebesar $61 \%, 5$ item dalam kategori baik dan 13 item sangat baik. Item pernyataan yang memiliki skor nilai terendah terletak pada indikator menguasai standar kompetensi dan kompetensi dasar mata pelajaran yang diampu.

3. Pengujian Hipotesis

Untuk mengetahui hubungan antara kompetensi profesional guru dengan pengalaman mengajar guru maka perlu dilakukan pengujian hipotesisya. Dimulai dengan analisis uji hipotesis, menentukan $r_{\text {tabel }}$, dan penentuan hipotesis.

a. Analisis Uji Hipotesis

Analisis uji hipotesis dilakukan guna untuk mengetahui korelasi kompetensi profesional guru sebagai variabel $\mathrm{X}$ terhadap pengalaman mengajar guru sebagai variabel $\mathrm{Y}$. Nilai korelasi $\mathrm{X}$ dan $\mathrm{Y}$ tersebut 
diketahui melalui analisis statistik yaitu korelasi product moment, adapaun rumus yang digunakan adalah sebagai berikut:

$$
r_{x y}=\frac{N \Sigma x y_{-\left(\sum x\right)}\left(\sum y\right)}{\sqrt{\left(N \Sigma x^{2}-\left(\sum x\right)^{2}\left(N \Sigma y^{2}-(\Sigma y)^{2}\right)\right.}}
$$

Setelah semua data yang dibutuhkan mengenai kompetensi profesional guru dan pengalaman mengajar guru didapatkan maka selanjutnya adalah mengkorelasikan kedua data tersebut dengan menggunakan rumus di atas.

Tabel 3. Korelasi Variabel X dan Variabel Y

\begin{tabular}{|l|l|l|l|l|l|l|}
\hline No & Responden & $\mathbf{X}$ & $\mathbf{Y}$ & $\mathbf{X}^{\mathbf{2}}$ & $\mathbf{Y}^{\mathbf{2}}$ & $\mathbf{X Y}$ \\
\hline 1 & SSMI & 153 & 159 & 23409 & 25281 & 24327 \\
\hline 2 & NRHNN & 149 & 160 & 22201 & 25600 & 23840 \\
\hline 3 & NP & 149 & 160 & 22201 & 25600 & 23840 \\
\hline 4 & IKHW & 145 & 153 & 21025 & 23409 & 22185 \\
\hline 5 & SR & 161 & 170 & 25921 & 28900 & 27370 \\
\hline 6 & DS & 147 & 148 & 21609 & 21904 & 21756 \\
\hline 7 & WRDH & 150 & 150 & 22500 & 22500 & 22500 \\
\hline 8 & SRN & 148 & 163 & 21904 & 26569 & 24124 \\
\hline 9 & HRY & 151 & 158 & 22801 & 24964 & 23858 \\
\hline 10 & MRYTN & 161 & 171 & 25921 & 29241 & 27531 \\
\hline 11 & DD & 163 & 169 & 26569 & 28561 & 27547 \\
\hline 12 & MLYSH & 162 & 175 & 26244 & 30625 & 28350 \\
\hline \multicolumn{2}{|l}{ Total } & $\mathbf{1 8 3 9}$ & $\mathbf{1 9 3 6}$ & $\mathbf{2 8 2 3 0 5}$ & $\mathbf{3 1 3 1 5 4}$ & $\mathbf{2 9 7 2 2 8}$ \\
\hline
\end{tabular}

$$
\begin{gathered}
r_{x y}=\frac{N \Sigma x y_{-\left(\sum x\right)}\left(\sum y\right)}{\sqrt{\left(N \Sigma x^{2}-\left(\sum x\right)^{2}\left(N \Sigma y^{2}-(\Sigma y)^{2)}\right.\right.}} \\
r_{x y}=\frac{(12)(297228)-(1839)(1936)}{\sqrt{(12)(282305)-(3381921)-(12)(313154-(3748096)}} \\
r_{x y}=\frac{(3566736)-(3560304)}{\sqrt{(3387660-3381921)(3757848-3748096)}} \\
r_{x y}=\frac{6432}{\sqrt{(66966728)}} \\
r_{x y}=\frac{6432}{7481,091} \\
r_{x y}=0.8597
\end{gathered}
$$


Vol. 2, No. 2, (April 2020): 183-201

Dari perhitungan data di atas dapat diketahui bahwa terdapat korelasi antara variabel $\mathrm{X}$ dan variabel $\mathrm{Y}$ yaitu sebesar 0,8597. Dengan kata lain terdapat korelasi positif sebesar 0,8597 antara pengalaman mengajar kompetensi profesional guru.

b. Interpretasi

Untuk mengetahui tingkat korelasi antara variabel $\mathrm{X}$ dan variabel $\mathrm{Y}$ dapat digunakan nilai $\mathrm{r}_{\mathrm{xy}}$ untuk dibandingkan dengan interpretasi koefisiensi korelasi nilai " $r$ " seperti pada tabel berikut ini:

Tabel 4. Interpretasi koefisiensi korelasi terhadap nilai"“r"

\begin{tabular}{|c|l|l|}
\hline No & $\begin{array}{c}\text { Besarnya "r" } \\
\text { product moment }\end{array}$ & \multicolumn{1}{c|}{ Interpretasi } \\
\hline 1 & $0,00-0,199$ & $\begin{array}{l}\text { Antara variabel X dan variabel Y memang } \\
\text { terdapat korelasi akan tetapi korelasi } \\
\text { tersebut sangat lemah atau sangat rendah }\end{array}$ \\
\hline 2 & $0,20-0,399$ & $\begin{array}{l}\text { Antara variabel X dan variabel Y terdapat } \\
\text { korelasi sangat lemah atau sangat rendah }\end{array}$ \\
\hline 3 & $0,40-0,599$ & $\begin{array}{l}\text { Antara variabel X dan variabel Y terdapat } \\
\text { korelasi yang sedang atau cukup kuat }\end{array}$ \\
\hline 4 & $0,60-0,799$ & $\begin{array}{l}\text { Antara variabel X dan variabel Y terdapat } \\
\text { korelasi yang kuat atau tinggi }\end{array}$ \\
\hline 5 & $0,80-1,000$ & $\begin{array}{l}\text { Antara variabel X dan variabel Y terdapat } \\
\text { korelasi yang sangat kuat atau sangat tinggi }\end{array}$ \\
\hline
\end{tabular}
Sumber: (Sugiyono, 2015)

Interpretasi secara kasar dari perhitungan di atas dapat disimpulkan bahwa korelasi antara kompetensi profesional guru dan pengalaman mengajar guru adalah tinggi atau kuat sehingga korelasi tersebut diterima. Berdasarkan tabel di atas tersebut dapat diketahui bahwa nilai $\mathrm{r}_{\mathrm{xy}}$ menunjukkan korelasi antara kompetensi profesional guru dan pengalaman mengajar guru bertanda positif. Dimana nilai rxy berada pada kisaran antara 0,60-0,799 yang berarti variabel $\mathrm{X}$ dan $\mathrm{Y}$ terdapat korelasi yang kuat atau tinggi.

c. Menentukan Signifikansi

Setelah koefisiensi korlasi ditemukan, langkah selanjutnya yaitu adalah pengujian signifikansi. Pengujian ini digunakan untuk mengetahui apakah hubungan yang ditemukan itu berlaku untuk seluruh 
populasi atau tidak. Uji signifikansi tersebut dilakukan dengan menggunakan uji t, dengan menggunakan rumus di bawah ini:

$$
\begin{aligned}
\mathrm{t} & =\frac{r \sqrt{n}-2}{\sqrt{1}-r^{2}} \\
\mathrm{t} & =\underline{0,8597 \sqrt{12}-2} \\
\sqrt{1}-(0,8597)^{2} & \\
\mathrm{t} & =\underline{2.7185} \\
& 0,261 \\
\mathrm{t} & =10,4157
\end{aligned}
$$

Jika $t_{\text {hitung }} \geq \mathrm{t}_{\text {tabel }}$ maka $\mathrm{H}_{0}$ ditolak artinya hasil signifikan

Jika $t_{\text {hitung }} \leq \mathrm{t}_{\text {tabel }}$ maka $\mathrm{H}_{\mathrm{a}}$ diterima artinya hasil tidak signifikan

Berdasarkan perhitungan di atas tersebut $\alpha=0,05$ dan $n=12$. Uji satu pihak: $\mathrm{Dk}=\mathrm{n}-2=12-2=10$, berarti Dk adalah 10 sehingga didapatkan $\mathrm{t}_{\text {tabel }}=1,81246$

Setelah kita lihat Perhitungan di atas, maka dapat diketahui bahwa $t_{\text {hitung }} \geq \mathfrak{t}_{\text {tabel, }}$ atau dapat ditulis $10,4157 \geq 1,81246$ maka hipotesa alternatif $\mathrm{Ha}$ diterima dan $\mathrm{H}_{0}$ ditolak, yang artinya terdapat hubungan yang signifikan antara kompetensi profesional guru dengan pengalaman mengajar guru PAI di Madrasah Aliyah Negeri 3 Palembang.

Kemudian selanjutnya untuk mengetahui besarnya kontribusi antara variabel $\mathrm{X}$ dan variabel $\mathrm{Y}$ dapat ditentukan dengan menggunakan rumus koefisien determinasi, yaitu sebagai berikut:

$$
\begin{aligned}
& \mathrm{KP}=\mathrm{r}^{2} \times 100 \% \\
& \mathrm{KP}=(0,8597)^{2} \times 100 \% \\
& \mathrm{KP}=73.59 \%
\end{aligned}
$$

Nilai KP $=73,59 \%$

Hal ini dimaksudkan bahwa variabel $\mathrm{X}$ (kompetensi profesional guru) memberikan kontribusi terhadap variabel $\mathrm{Y}$ (pengalaman mengajar guru pai di Madrasah Aliyah Negeri 3 Palembang) sebesar $73,59 \%$ dan sisanya $26,41 \%$ dipengaruhi oleh variabel lain yang tidak termasuk kedalam penelitian ini. 


\section{B. Pembahasan}

Penelitian ini dilaksanakan di Madrasah Aliyah Negeri 3 Palembang. Proses penelitian ini dimulai dari tanggal 12 Juni 2019 sampai pada tanggal 14 Juni 2019. Dalam proses penelitian ini melalui beberapa tahapan proses yang dilakukan peneliti termasuk uji validitas dan realibititas instrumen.

Penelitian ini melibatkan seluruh guru biologi di Madrasah Aliyah Negeri 3 Palembang yang berjumlah 12 sampel. Data yang terkumpul berupa hasil tes kuesioner. Data dari hasil penelitian ini meliputi dua variabel yaitu variabel kompetensi profesional guru (X) dan variabel pengalaman mengajar guru (Y) yang dianalisis menggunakan korelasi product moment.

1. Pengalaman Mengajar Guru PAI di Madrasah Aliyah Negeri 3 Palembang.

Hasil analisis data mengenai pengalaman mengajar guru mata pelajaran PAI di Madrasah Aliyah Negeri 3 Palembangmenunjukkan bahwa pengalaman mengajar guru di Madrasah Aliyah Negeri 3 Palembang berada dalam kategori yang sangat baik, Pengkategorian skor berdasarkan persentase skor aktual dimana apabila persentase skor 20,0036,00 maka berada pada kategori sangat rendah/tidak baik, apabila persentase skor 36,01-52,00 berada dalam kategori rendah/kurang baik, apabila persentase berada pada 52,01-68,00 maka berada pada kategori cukup tinggi/cukup baik, selanjutnya apabila persentase berada pada angka 68,00-84,00 berada dalam kategori tinggi/baik, dan apabila persentase berada pada angka 84,01-100,0 maka dapat dikategorikan sangat tinggi/sangat baik (Narimawati, 2007). Hal ini dapat diketahui dari indikator kompetensi dibawah ini:

a. Pendidikan dan Pelatihan Mengajar

Pada indikator kompetensi ini terdiri atas 6 item pernyataan, perhitungan secara lengkap. Pada item pernyataan pertama berada dalam kategori sangat baik yaitu dengan jumlah nilai $89 \%$, selanjutnya pada item pernyataan kedua juga memiliki kategori sangat baik yaitu dengan jumlah nilai 93\%, pada item pernyataan ketiga juga dalam 
kategori sangat baik yaitu dengan jumlah nilai 95\%, kemudian pada item pernyataan keempat dengan jumlah nilai $86 \%$ juga berada dalam kategori sangat baik. Selanjutnya pada item pernyataan kelima dengan jumlah nilai $89 \%$ juga dalam kategori sangat baik, dan yang terakhir pada item pernyataan keenam dengan jumlah nilai $92 \%$ juga menunjukkan alam kategori baik.

Secara keseluruhan pada indikator pendidikan dan pelatihan mengajar menguasai teori belajar dan prinsip-prinsip belajar yang mendidik telah menunjukkan bahwa pengalaman guru telah berjalan dengan sangat baik, terbukti dari jumlah hasil jawaban responden pada tiap item pernyataan yang telah menunjukkan hasil bahwa setiap item pernyataan tergolong dalam kategori sangat baik.

Sebagai seorang pendidik, tugas guru tidak hanya wajib menguasai kurikulum dan tugas-tugas kependidikan tetapi hendaknya mengenali peserta didik terlebih karakteristik mereka. Karakteristik peserta didik yang perlu dikenal dan dipahami oleh guru tidak hanya terbatas pada tipe kepribadiannya saja, tetapi juga melingkup kebutuhan belajar, kemampuan mereka dalam belajar, potensi yang dimiliki, dan lingkungan yang ada di sekitar mereka.

b. Kesempatan Mengajar

Pada indikator kompetensi ini terdiri atas 6 item pernyataan. Pada item ketujuh menunjukkan berada dalam kategori sangat baik dengan jumlah nilai 93\%, selanjutnya item pernyataan kedelapan juga berada dalam kategori sangat baik dengan jumlah nilai 90\%, lalu pada item pernyataan kesembilan dengan jumlah nilai $89 \%$ juga dapat menunjukkan berada dalam kategori sangat baik, pada item pernyataan kesepuluh juga menunjukkan dalam kategori sangat tinggi yaitu dengan nilai 96\%, selanjutnya pada item pernyataan kesebelas dengan jumlah nilai 98\% juga berada dalam kategori sangat baik. Dan pada item pernyataan keduabelas juga menunjukkan kategori sangat baik yaitu dengan nilai $94 \%$. 
Dari hasil di atas tersebut maka dapat diketahui, bahwa pada indikator kesempatan mengajar yang mendidik telah berjalan dengan baik, dapat dilihat dari hasil jawaban tiap item pernyataan yang berada dalam kategori sangat baik. Namun demikian guru pai di Madrasah Aliyah Negeri 3 Palembang harus terus meningkatkan pengalaman mengajarnya.

\section{c. Lama Mengajar}

Pada indikator kompetensi ini terdiri dari 8 item pernyataan, Pada item pernyataan ketigabelas menunjukkan nilai $89 \%$ yang dikategorikan dalam kategori sangat baik, kemudian item pernyataan keempat belas dengan jumlah nilai $100 \%$ dikategorikan dalam kategori sangat baik, selanjutnya pada item pernyataan kelima belas juga menunjukkan hasil yang sangat baik yaitu dengan jumlah nilai $100 \%$, dan pada item pernyataan ke-enambelas menunjukkan kategori sangat baik juga yaitu dengan jumlah nilai $94 \%$.

Dari hasil di atas tersebut maka dapat diketahui, bahwa pada indikator lama mengajar telah menunjukkan hasil kerja yang berada dalam kategori sangat baik

\section{Kompetensi Profesional Guru}

Hasil analisis data mengenai kompetensi profesional guru memperlihatkan bahwa kompetensi profesional memiliki pengaruh yang signifikan terhadap pengalaman mengajar guru. Pengkategorian skor berdasarkan persentase skor aktual dimana apabila persentase skor 20,0036,00 maka berada pada kategori sangat rendah/tidak baik, apabila persentase skor 36,01-52,00 berada dalam kategori rendah/kurang baik, apabila persentase berada pada 52,01-68,00 maka berada pada kategori cukup tinggi/cukup baik, selanjutnya apabila persentase berada pada angka 68,00-84,00 berada dalam kategori tinggi/baik, dan apabila persentase berada pada angka 84,01-100,0 maka dapat dikategorikan sangat tinggi/sangat baik. Hal ini dapat dilihat dari hasil masing-masing indikator kompetensi profesional yang akan dijabarkan di bawah ini: 
a. Menguasai Mata Pelajaran yang Diampu

Pada indikator ini terdiri atas 5 item pernyataan, perhitungan secara lengkap dapat dilihat pada tabel 8 dapat dijabarkan sebbagai berikut: Pada item pernyataan pertama memiliki kriteria sangat baik dengan jumlah 99\%, item pernyataan kedua memiliki kriteria sangat baik dengan jumlah $100 \%$, selanjutnya item pernyataan ketiga memiliki kriteria baik dengan jumlah $75 \%$, item pernyataan keempat memiliki kriteria sangat baik dengan jumlah 93\%, kemudian item pernyataan kelima memiliki kriteria baik dengan jumlah $78 \%$.

Seorang guru harus memahami dan menguasai materi pembelajaran, hal ini penting yang harus dimiliki guru adalah kemampuan menjabarkan materi. Guru harus mampu menentukan secara tepat materi yang relevan dengan kebutuhan dan kemampuan peserta didik.

Dari data tersebut dapat diketahui bahwa guru PAI di Madrasah Aliyah Negeri 3 Palembang telah memiliki kompetensi profesional yang sangat baik pada indikator menguasai mata pelajaran yang diampu. Namun perlu mengembangkan kompetensi profesionalnya pada item pernyataan ketiga yaitu saya menjelaskan materi pembelajaran tanpa melihat buku teks/pegangan dan item pernyataan kelima mengenai saya mengaitkan materi pembelajaran yang saya sampaikan dengan materi pelajaran lain.

b. Menguasai Standar Kompetensi dan Kompetensi Dasar Mata Pelajaran yang Diampu

Pada indikator ini terdiri atas 11 item pernyataan, perhitungan secara lengkap dapat dilihat pada tabel 8 dapat dijabarkan sebagai berikut: Pada item pernyataan keenam memiliki kategori baik dengan jumlah $84 \%$, item pernyataan ketujuh dengan jumlah 94\% memiliki kategori sangat baik, selanjutnya item pernyataan kedelapan memiliki kategori sangat baik dengan jumlah $96 \%$, item pernyataan kesembilan juga berada dalam kategori sangat baik dengan jumlah 97\%, item pernyataan kesepuluh dengan jumlah $90 \%$ juga berada dalam kategori 
sangat baik. Selanjutnya pada item pernyataan kesebelas pula menunjukkan kategori yang sangat baik yaitu sebesar 90\%, namun pada item pernyataan kedua belas menunjukkan kompetensi guru pada indikator ini memiliki kategori kurang baik yaitu 53\%, pada item pernyataan ketiga belas juga menunjukkan bahwa kompetensi profesional tidak berjalan dengan baik atau dalam kategori cukup dengan nilai $61 \%$, selanjutnya pada item pernyataan keempat belas memiliki kategori sangat tinggi dengan nilai 99\%, item pernyataan kelima belas $96 \%$ dan item pernyataan keenam belas sebesar $94 \%$.

Dalam penguasaan standar kompetensi dan kompetensi dasar mata pelajaran yang diampu/bidang pengembangan yang diampu mengingat prinsip-prinsip pengembangan kurikulum dan pemilihan bahan ajar diantaranya sebagai berikut: (1) Orientasi pada tujuan dan kompetensi, (2) Kesesuaian/relevansi, (3) Efesiensi dan efektif, (4) Kesenambungan dan berimbang, (5) Kemenarikan, (6) Kepuasan (Hamalik, 2011).

Dari data tersebut dapat kita ketahui bahwa kompetensi profesional guru yang belum terpenuhi dengan baik dan perlu dikembangkan yaitu pada item pernyataan kedua belas yaitu saya mengembangkan sendiri kompetensi dasar pada materi yang saya sampaikan, dan pada item pernyataan ketiga belas yaitu saya menambahkan kompetensi dasar pada materi yang saya sampaikan. Namun pada indikator ini secara keseluruhan kompetensi profesional sudah berjalan dengan baik hanya saja perlu dikembangkan.

c. Mengembangkan Materi Yang Diampu Secara Kreatif

Pada indikator ini terdiri atas 3 item pernyataan, perhitungan secara lengkap dapat dilihat pada tabel 8 yang dapat dijabarkan sebagai berikut: Pada item pernyataan ketujuh belas memiliki jumlah 89\% dengan kategori sangat baik, selanjutnya item pernyataan kedelapan belas dengan jumlah $83 \%$ dalam kategori baik, kemudian item pernyataan kesembilan belas juga berada dalam kategori sangat baik dengan jumlah 86\%. Dari keseluruhan hasil tiap item pada 
indikator ini telah menunjukkan bahwa kompetensi profesional telah berjalan dengan baik namun tidak menutup kemungkinan untuk terus dikembangkan agar kompetensi profesional guru terus meningkat.

Menurut Hamalik (2011), terdapat tiga tipe pembelajaran yang menyangkut peran guru mengembangkan dan menyampaikan pembelajaran diantaranya:

1) Jika guru mendesain dan mengembangkan materi pembelajaran materi bersifat pasif, tugas guru adalah memotivator dan membimbing kemajuan peserta didik dalam menyelesaikan materi dan membentuk kompetensi

2) Guru memilih materi pembelajaran yang telah ada dan menyesuaikan dengan strategi pembelajaran yang digunakan, untuk membentuk peranan menjadi lebih aktif dalam penyampaian materi dan pembentukan kompetensi

3) Pembelajaran sangat tergantung kepada guru, guru menyampaikan semua mater pembelajaran menurut strategi yang telah dikembangkan.

d. Mengembangkan Keprofesionalan Secara Berkelanjutan dengan Melakukan Tindakan Reflektif

Pada indikator ini terdiri atas 1 item pernyataan, perhitungan secara lengkap dapat dilihat pada tabel 8 yang dapat dijabarkan sebagai berikut: Pada item pernyataan kedua puluh memiliki kategori baik dengan nilai $71 \%$, Dalam indikator mengembangkan keprofesionalan secara berkelanjutan dengan melakukan tindakan reflektif ini dapat diketahui sub indikator yang perlu dikembangkan lagi yaitu pada item pernyataan keduapuluh yaitu saya mengkoreksi kelebihan saya sendiri dalam menyampaikan materi pembelajaran. Kemudian item pernyataan ke-duapuluh enam yaitu saya melakukan penelitian tindakan kelas untuk melihat kekurangan yang dialami siswa dalam proses pembelajaran. Selanjutnya pada item pernyataan keduapuluh tujuh yaitu saya melakukan penelitian tindakan kelas untuk melihat kekurangan saya dalam proses pembelajaran. Kemudian 
yang terakhir yang perlu dikembangkan pada indikator ini yaitu item pernyataan keduapuluh delapan yaitu saya melakukan penelitian tindakan kelas yang sangat penting untuk meningkatkan keprofesionalan.

Dalam UU RI No. 14 Tahun 2005 tentang guru dan dosen, dikemukakan bahwa "Organisasi profesi guru adalah perkumpulan yang dibadan hukum yang didirikan dan diurus oleh guru untuk mengembangkan profesionalitas guru". Dalam hal ini maka dapat kita ketahui bahwa guru harus merencakan dan melaksanakan program atau kegiatan yang berkaitan dengan perbaikan cara mengajar, peningkatan pengetahuan dan keterampilan guru peningkatan kualitas guru atau melakukan penelitian ilmiah tentang masalah-masalah profesional yang dihadapi oleh para guru.

\section{KESIMPULAN}

Berdasarkan hasil penelitian mengenai hubungan pengalaman mengajar dengan kompetensi profesional guru PAI di Madrasah Aliyah Negeri 3 Palembang yang telah diuraikan pada bab sebelumnya maka dapat disimpulkan bahwa terdapat korelasi positif yang sangat baik antara pengalaman mengajar guru dengan kompetensi profesional guru PAI di Madrasah Aliyah Negeri 3 Palembang. Hal ini membuktikan bahwa hubungan antara pengalaman mengajar guru dengan kompetensi profesional guru PAI di Madrasah Aliyah Negeri 3 Palembang berkorelasi positif. Dengan demikian dapat diketahui bahwa hipotesis yang diajukan diterima yaitu terdapat korelasi yang signifikan antara pengalaman mengajar guru dengan kompetensi profesional guru PAI di Madrasah Aliyah Negeri 3 Palembang.

Korelasi antara pengalaman mengajar guru dengan kompetensi profesional guru PAI di Madrasah Aliyah Negeri 3 Palembang yang diperoleh adalah 0,8597 yang berarti terdapat korelasi yang positif antara pengalaman mengajar guru dengan kompetensi profesional guru PAI di Madrasah Aliyah Negeri 3 Palembang. Dengan melakukan uji t untuk memperoleh signifikansi hubungan antara kedua variabel tersebut diperoleh $t_{\text {hitung }}$ sebesar 10,4157. dari perhitungan 
tersebut menyatakan bahwa $t_{\text {hitung }}>t_{\text {tabel }}$ sehingga hubungan antara pengalaman mengajar guru dengan kompetensi profesional guru PAI di Madrasah Aliyah Negeri 3 Palembang adalah sangat signifikan. 
Vol. 2, No. 2, (April 2020): 183-201

\section{DAFTAR PUSTAKA}

Darmadi, Hamid. Metode Peneltian Pendidikan dan Sosial. Bandung: Alfabeta, 2014.

Martina, Nyayu Khodijah, dan Syarnubi. "Pengaruh Lingkungan Sekolah Terhadap Hasil Belajar Siswa Pada Mata Pelajaran Pendidikan Agama Islam Di SMP Negeri 9 Tulung Selapan Kabupaten OKI.” Jurnal PAI Raden Fatah 1 (2): 164-180.

Noor, Juliansyah. Metodologi Penelitian: Skripsi, Tesis, Disertai, dan Karya Ilmiah. Jakarta: Kencana, 2011.

Rojai. Panduan Sertifikasi Guru Berdsarkan Undang-Undang Guru dan Dosen. Jakarta: Bumi Aksara, 2007.

Sanjaya, Wina. Penelitian Pendidikan. Jakarta: Kencana, 2015.

Sugiyono. Metode Penelitian Kuantitatif, Kualitatif, dan Kombinasi (Mix Methods). Bandung: Alfabeta, 2015.

Supardi. Metodologi Penelitian Pendidikan. Jakarta: Bumi Aksara, 2007.

Uno, Hamzah B. Profesi Kependidikan. Jakarta: Bum iAksara, 2012.

Wibowo. Manajemen Kinerja. Jakarta: Raja Grafindo Perkasa, 2104.

Yusuf, A. Murni. Metodelogi Penelitian: Kuantitatif, Kualitatif \& Penelitian Gabungan. Jakarta: Prenadamedia Group, 2016.

Zaini, Herman. Kompetensi Guru PAI. Palembang: NoerFikri Offset, 2105. 